\title{
A Child with Right Complete Ureteral Duplication Revealed by Sepsis in Northern Benin: A Case Report
}

Agbeille Mohamed $\mathrm{F}^{1^{*}}$, Agossou $\mathrm{J}^{1}$, Gandaho ${ }^{2}$, Kpanidja $\mathrm{MG}^{1}$, Noudamadjo A ${ }^{1}$, Adédémy JD ${ }^{1}$

${ }^{1}$ Department of Mother and Child, Faculty of Medicine, University of Parakou and Pediatric Unit of the Borgou/Alibori Regional Teaching Hospital

${ }^{2}$ Department of Surgery and Surgical Specialties, Faculty of Medicine, University of Parakou

Corresponding Author: Falilatou AGBEILLE MOHAMED

Address: Pediatrician, Faculty of Medicine, University of Parakou; Tel: +229 95768882; E-mail: fmagbeille@yahoo.fr Received date: 16 January 2020; Accepted date: 24 February 2020; Published date: 02 March 2020

Citation: Agbeille Mohamed F, Agossou J, Gandaho I, Kpanidja MG, Noudamadjo A, Adédémy JD. A Child with Right Complete Ureteral Duplication Revealed by Sepsis in Northern Benin: A Case Report. Asp Biomed Clin Case Rep. 2020 Mar 02;3(1):71-74.

Copyright (C) 2020 Agbeille Mohamed F, Agossou J, Gandaho I, Kpanidja MG, Noudamadjo A, Adédémy JD. This is an open-access article distributed under the Creative Commons Attribution License, which permits unrestricted use, distribution, and reproduction in any medium provided the original work is properly cited.

\begin{abstract}
Upper urinary tract abnormalities are relatively common and may be diagnosed before or at birth. Some cases will be seen during complications that most often are obstructive. We herein report one case of complete right ureter duplication revealed by sepsis. The case involved one little girl aged 3 years, referred from a peripheral health center for prolonged fever. Physical examination found out a right flank mass connecting with the lumbar spine, renal ballottement, and pain due to a blow to the right flank. Further explorations helped establish the diagnosis of complete duplication of the right ureter with the destruction of the upper renal pelvis. Little girl benefitted from a dual antibiotic therapy combined with partial nephrectomy of the right kidney upper pole. Infectious are serious complications in upper urinary tract obstructions resulting in kidney destruction; therefore, early diagnosis is required.
\end{abstract}

\section{Keywords}

Ureteral Duplication; Sepsis; Nephrectomy; Child

\section{Introduction}

Ureteral duplication is one of the most common defects of a child's urinary tract [1]. It is reflected by the existence of two pelves drained by two ureters at the level of one or of both kidneys. Its clinical expression is variable. More often asymptomatic it can be discovered incidentally during a medical examination performed for other diseases. Sometimes, it may be revealed during serious complications, such as repeated urinary tract infections and even septicemia with the destruction of the renal parenchyma. We herein report the case of complete ureteral duplication revealed by severe sepsis in a 3-year little girl in the pediatric unit of Borgou/Alibori Regional teaching Hospital in Northern Benin.

\section{Observation}

The subject was a 3-year little girl, with no particular medical history, referred from a peripheral health center for prolonged fever. That fever which oscillated between 39 and $40^{\circ} \mathrm{C}$ has been progressing for two weeks, associated with food vomiting, hypogastric pain and release of dark urines. The physical examination had identified an altered general state, a temperature of $38^{\circ} 5 \mathrm{c}$, a heart rate (HR) 
Citation: Agbeille Mohamed F, Agossou J, Gandaho I, Kpanidja MG, Noudamadjo A, Adédémy JD. A Child with Right Complete Ureteral Duplication Revealed by Sepsis in Northern Benin: A Case Report. Asp Biomed Clin Case Rep. 2020 Mar 02;3(1):71-74.

\section{Case Report}

estimated at 180 beats per minute (bpm), a respiratory rate of 50 counts per min, a blood pressure of 100/6ommhg, cold hands, an extended time of recoloring; and a weight of $17 \mathrm{Kg}$. Abdominal palpation made it possible to find out a smooth, renitent and painful right flank mass in contact with the lumbar spine. Genital organs were normal. The urine test strip had revealed the presence of white blood cells and nitrites.

An abdominal ultrasound had shown a fluid mass with heterogeneous content pushing the right kidney downwards. The contralateral kidney was normal. Uropelvic computed tomography had highlighted a heterogeneous fluid mass located in the medial cranial part of the right kidney with spur sign. The right ureter was visible in the back of the mass (Fig-1). The cyto-bacteriological examination of urine

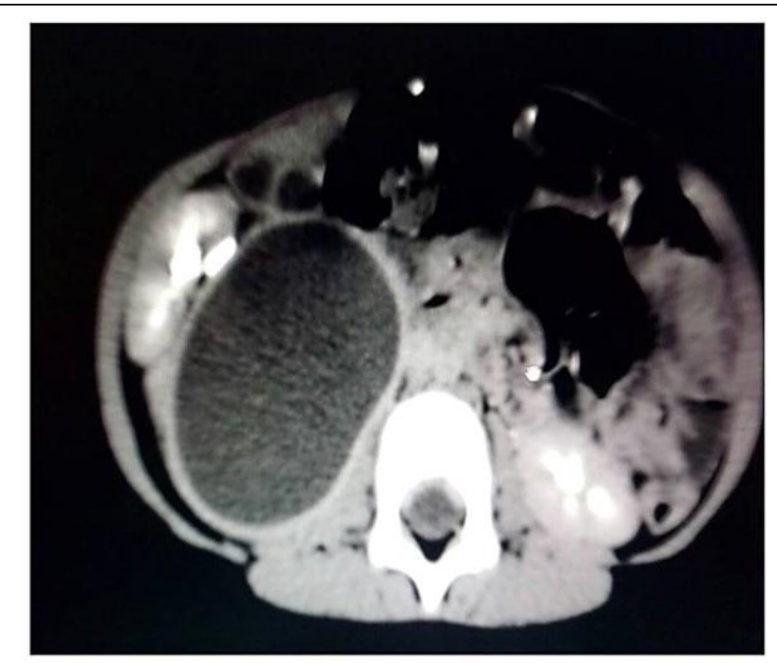

Fig-1: The right hydronephrosis by pelvic Tomography scanner

with culture and antibiogram had highlighted leukocyturia of $12000 / \mathrm{ml}$, bacteriuria estimated at $10^{6} / \mathrm{ml}$ with isolation and identification of Klebsiella Oxytoca which was sensitive, among others, to gentamycin. Complete blood count had revealed hyperleukocytosis at $23 \mathrm{G} / \mathrm{L}$ with the predominance of polymorphonuclear leukocytes (75\%). C-reactive protein was positive at $48 \mathrm{mg} / \mathrm{L}$. The blood concentration of creatinine was normal at $8 \mathrm{mg} / \mathrm{L}$. As regards therapy, the little girl received a vascular filling with a salted serum of 9/100o concentration. This was followed by antibiotic therapy consisting of ceftriaxone with a dosage of $100 \mathrm{mg} / \mathrm{kg} / \mathrm{j}$ during 10 days combined with gentamycin for 5 days. Partial nephrectomy of the upper pole had been performed a second time. In the preoperative phase, two collecting systems had been identified on the right side: ureter of the upper renal pelvis was dilated with 750cc of dark urine and parenchyma was completely wiped out; the parenchyma and ureter of the lower renal pelvis were normal (Fig-2). Postoperative side-effects have been simple. The cytobacteriological examination of urine cultures was normal after treatment. The little girl after doing well has been seen regularly.

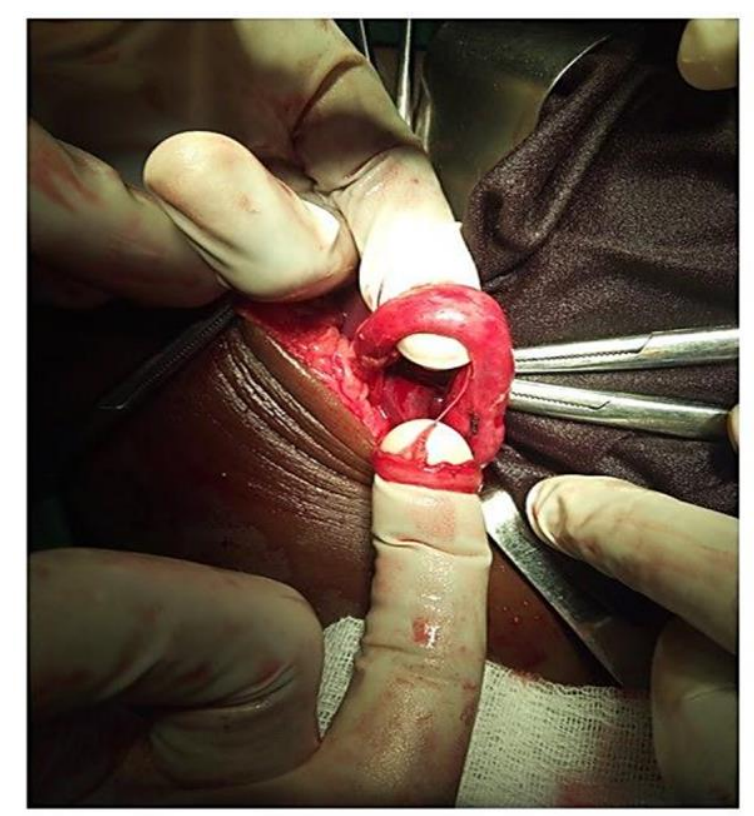

Fig-2: The complete ureteral duplication in the preoperative phase

\section{Discussion}

Ureteral duplication is a common malformation of the urinary tract. One child out of 125 is carrying this anomaly. Female subjects are the most affected [2]. The right and left kidneys are equally affected; which may be bilateral in 20 to $40 \%$ [1].

Anatomically, two variants are described: partial duplication or ureteral bifidity, and complete duplication or ureteral duplicity. In the partial form, the two ureters originate from the kidney and join together at a variable level before liaising with the bladder. In the complete form, both ureters are independent throughout their route till ureteropelvic junction [1]. There are uncommon forms: inverted duplication $[2,3]$. Sometimes, they may be associated with other malformations: vesicoureteric reflux, 
Citation: Agbeille Mohamed F, Agossou J, Gandaho I, Kpanidja MG, Noudamadjo A, Adédémy JD. A Child with Right Complete Ureteral Duplication Revealed by Sepsis in Northern Benin: A Case Report. Asp Biomed Clin Case Rep. 2020 Mar 02;3(1):71-74.

Case Report

ureterocele, megalo-ureter and ectopic anastomosis [4,5]. In our case, it was right ureter duplicity characterized by an ectopic anastomosis of the ureter of the upper renal pelvis with the bladder.

Ultrasound contributes significantly to the antenatal diagnosis of urogenital malformations; however, it remains very moderately specific as regards ureteral duplicity. For instance, hydronephrosis is the joint ultrasound expression [5], only postnatal radiological monitoring helps determine with accuracy the etiology of that dilatation. In the postnatal period, clinical expression depends on the expressive renal pelvis. Indeed, upper renal pelvis is often associated with ectopic ureter anastomosis, which is a source of urine loss or obstruction to urine flow, most often asymptomatic. In contrast, the lower renal pelvis is a fertile ground for vesicorénal reflux. [1,2,4].

Urinary infection is the main circumstance of malformation diagnosis [4]. In our female patient, it manifested itself by pyelonephritis complicated by a septic shock that may have left her dead. In the little girl, ureteral ectopy may occur as persistent urinary incontinence despite the frequency of normal mictions. It is difficult, for parents, to notice incontinence before the child's age of cleanliness and hygiene, which may explain the delay in diagnosis [2] as was the case of our patient. Ureteral duplicity is confirmed by the identification of two collecting systems at the level of a single kidney. The most effective examinations in this detection are intravenous urogram (IVU) or intravenous pyelogram (IVP), computed tomography (CT) of the kidneys and magnetic resonance imaging (MRI) [5-7]. In the case of our patient, the computed tomography (CT) of the kidneys performed did not contribute very significantly. For instance, ureteral dilatation was so significant on the upper renal pelvis that it was considered as a renal cyst.

Treatment consisted of two components. Medical management of pyelonephritis was ensured through a dual antibiotic therapy with satisfactory clinical progression. Surgical care consists in performing nephrectomy of the kidney's upper pole. This therapeutic option was chosen because it was described that the kidney area drained by an ectopic ureter is often non-functional and with dysplasia [8]. It is a semi-conservative treatment of the kidney. Resources are available to assess the functionality of the upper renal pelvis $[9,10]$.

Although partial nephrectomy for the upper urinary tract was performed, the risk for vesicoureteric reflux was not excluded on the main ureter. Therefore, patient regular follow-up is required for early detection and management of that anomaly. Ultrasound predictive criteria were developed for the diagnosis of vesicoureteric reflux.

\section{Conclusion}

As a malformation, ureteral duplication is common among children. It consists of two anatomic forms: ureteral duplicity and ureteral bifidity. In the context of ureteral duplicity, signs are noisy when other malformations are associated with it, especially vesicoureteric reflux and ectopic anastomosis cases. Urinary infection is the main way of the revelation of that malformation. Therefore, early diagnosis is urgently necessary.

\section{Acknowledgment}

The authors thank sincerely Pr Savi de Tove Kofi Mensa for providing the precious CT images.

\section{Declaration of Interest}

The authors declare that there is no conflict of interest.

\section{References}

[1] Nepple KG, Cooper CS, Snyder III HM. Ureteral duplication, ectopy, and ureteroceles. Pediatric Urology. 2010 Jan 1 (pp. 337-352). WB Saunders.

[2] Salakos C, Tyritzis SI, Papanastasiou D, Geropoulou E, Constantinides CA. Double-blind ureteral duplication: a rare urologic anomaly. Urology. 2009 Jan;73(1):210.e1-2. [PMID: 18372014]

[3] Souffrant D, Hagerty J, Colon-Sanchez K, Epelman $\mathrm{M}$, Ellsworth P. Intermittent Urinary Incontinence Secondary to Inverted-Y Ureteral Duplication With Perianal Ectopia. Urology. 2019 May;127:124-26. 
Citation: Agbeille Mohamed F, Agossou J, Gandaho I, Kpanidja MG, Noudamadjo A, Adédémy JD. A Child with Right Complete Ureteral Duplication Revealed by Sepsis in Northern Benin: A Case Report. Asp Biomed Clin Case Rep. 2020 Mar 02;3(1):71-74.

\section{Case Report}

[PMID: 30822476]

[4] Sencan A, Carvas F, Hekimoglu IC, Caf N, Sencan A, Chow J, Nguyen HT. Urinary tract infection and vesicoureteral reflux in children with mild antenatal hydronephrosis. J Pediatr Urol. 2014 Dec;10(6):10o813. [PMID: 24863985]

[5] Gatti J, Murphy J, Williams J, Harry P. Koo, Mary LW, Martin David B. E-medecine Medscape. Ureteral Duplication, Ureteral Ectopia, and Ureterocele. Updated: Dec 02, 2019.

https://emedicine.medscape.com/article/1017202overview

[6] Dy GW, Ellison JS, Fu BC, Holt SK, Gore JL, Merguerian PA. Variable Resource Utilization in the Prenatal and Postnatal Management of Isolated Hydronephrosis. Urology. 2017 Oct;108:155-6o. [PMID: 28583878]

[7] Lee JN, Kang JK, Jeong SY, Lee SM, Cho MH, Ha YS, Kim HT, Kim TH, Yoo ES, Kwon TG, Chung SK. Predictive value of cortical transit time on MAG3 for surgery in antenatally detected unilateral hydronephrosis caused by ureteropelvic junction stenosis. J Pediatr Urol. 2018 Feb;14(1):55.e1-55.e6. [PMID: 28988673]

[8] Neheman A, Kord E, Strine AC, VanderBrink BA, Minevich EA, DeFoor WR, Reddy PP, Noh PH. Pediatric Partial Nephrectomy for Upper Urinary Tract Duplication Anomalies: A Comparison Between Different Surgical Approaches and Techniques. Urology. 2019 Mar;125:196-201. [PMID: 30476504]

[9] Rickard M, Lorenzo AJ, Braga LH. Renal Parenchyma to Hydronephrosis Area Ratio (PHAR) as a Predictor of Future Surgical Intervention for Infants With High-grade Prenatal Hydronephrosis. Urology. 2017 Mar;101:85-89. [PMID: 27713070]

[10] Plaire JC, Pope JC 4th, Kropp BP, Adams MC, Keating MA, Rink RC, Casale AJ. Management of ectopic ureters: experience with the upper tract approach. J Urol. 1997 Sep;158(3 Pt 2):1245-47. [PMID: 9258185] 